\title{
Assessment of Heavy Metals in Surface Water and Bottom Sediment of Ekpan Creek, Effurun, Delta State, Nigeria
}

\author{
Oluowo Elohor Freeman $^{1^{*}}$ and Isibor Patrick Omoregie ${ }^{1}$ \\ ${ }^{1}$ Department of Animal and Environmental Biology, Faculty of Life Sciences, University of Benin, \\ Benin City, Nigeria.
}

Authors' contributions

This work was carried out in collaboration between both authors. Author OEF designed the work, carried out the field studies, statistics and wrote the first manuscript. Author IPO carried out the laboratory analysis and contributed to manuscript correction. Both authors read and approved the final

manuscript.

Article Information

DOI: $10.9734 / J A L S I / 2016 / 29144$

Editor(s):

(1) Purnachandra Nagaraju Ganji, Department of Hematology and Medical Oncology, Emory University School of Medicine,

USA.

Reviewers:

(1) Ikama E. Uwah, University of Calabar, Calabar, Nigeria.

(2) Isa Baba Koki, Northwest University Kano, Nigeria.

(3) Hasrizal Bin Shaari, Universiti Malaysia Terengganu, Malaysia.

Complete Peer review History: http://www.sciencedomains.org/review-history/16610

Original Research Article

Received $25^{\text {th }}$ August 2016

Accepted $14^{\text {th }}$ October 2016

Published $20^{\text {th }}$ October 2016

\begin{abstract}
The accumulation of heavy metals in water and sediment of Ekpan Creek has increased significantly from previously reported concentrations. The present study was designed to assess the levels of heavy metals in surface water and sediment in the Creek using scientifically recommended procedures for seven (7) heavy metals levels of Iron (Fe), Zinc (Zn), Copper (Cu), Lead $(\mathrm{Pb})$, Chromium ( $\mathrm{Cr})$, Cadmium ( $\mathrm{Cd})$ and Maganese $(\mathrm{Mn})$. The concentrations of these metals were determined using the Atomic Absorption Spectrometer (AAS) and Inductively Coupled Plasma-Mass Spectrometer (ICPMS) metal scanning respectively. Their order of prevalence in water was $\mathrm{Fe}>\mathrm{Zn}>\mathrm{Mn}>\mathrm{Cd}>\mathrm{Pb}>\mathrm{Cu}>\mathrm{Cr}$, while sediment was $\mathrm{Fe}>\mathrm{Cu}>\mathrm{Mn}>\mathrm{Cr}>\mathrm{Pb}>\mathrm{Zn}>\mathrm{Cd}$. Fe and $\mathrm{Cu}$ recorded worrisome levels above regulatory limits in some stations. This requires urgent efforts to monitor the sources of heavy metals to the river, their bioaccumulation in icthyofauna of the river and public health risk assessment.
\end{abstract}

${ }^{*}$ Corresponding author: E-mail: hallabigfreeman@gmail.com; 
Keywords: Surface water; bottom sediment; heavy metals; sorption, Ekpan Creek.

\section{INTRODUCTION}

The daily accumulation of heavy metals in the environment (particularly coastal waters) has increased significantly due to increasing anthropogenic activities; thus pollution of aquatic water bodies. Although, metals are present naturally in trace amount in freshwaters from the weathering of rocks and soils, they become toxic when a particular level is reached. For instance, essential metals such as, Manganese, Zinc, Copper, Iron and Nickel, when present in trace concentrations are important for the physiological functions of living tissues and regulate many biochemical processes [1,2], but can become toxic as non-essential heavy metals when they are in excess amounts.

The ability of a water body to support aquatic life as well as its suitability for other uses depends largely on many of these trace elements, which naturally through precipitation and atmospheric deposition, have significant amounts entering the hydrological circle through surface waters [3-5]. The most worrisome is the anthropogenic releases from industrial and domestic wastewater sources, the burning of fossil fuels, land run-off, oil spill, gas leaks, blow outs, canalization and discharge from oil and gas operations into surface water bodies or release from industrial operations such as mining, canning and electroplating.

Damages caused by these activities are enormous which includes changes in water quality, loss of flora and important icthyofauna of water bodies, health and ecological risk when bio-accumulated to the life supporting functions and ecosystem services they provide.

Due to hydrodynamics, inland aquatic ecosystems are interconnected and as a result of their physical, chemical and biological characteristics they exhibit a high natural variability [2] and as such, more susceptible to anthropogenic influence than the more consistent and stable marine ecosystems [6].

Some of the effects resulting from metal toxicity and their sources have been widely reported by different authors such as Ajao and Fagade [7], Fufeyin [8], Erema and Hawkins [9], Ayenimo et al. [10,11], Emoyan et al. [2], Nduka and Orisakwe [12], Puyate et al. [13], Olomukoro and Azubuike [14], Steven and Nwabuk [15], USEPA [16] and Isibor and Oluowo [17].
Heavy metals are defined as metals having densities greater than $5 \mathrm{~g} / \mathrm{cm}^{-3}$ [5] and with atomic weight of $40 \mathrm{~g}$ and above. They are reported to occur naturally in ores, usually as a combination of several metals in organic or inorganic forms. So also, their release in the environment is almost entirely from ores. They are found in natural waters as particulates or soluble organics or inorganics [8].

The bottom sediments serve as a reservoir for heavy metals, and therefore deserve a special consideration in the planning and design of pollution research studies. Benthic studies of the brackish aquatic environment in Nigeria, according to Olomukoro and Azubuike [14] have been very scanty due to the difficulty in accessing the creeks, creeklets and estuaries has restricted ecologist from the survey of Nigerian coastal area.

Sediments are important sinks to various pollutants like trace metals and play an important role in the elemental cycling in the aquatic environment. They also mediate uptake, storage, release and transfer between environmental compartments [18].

Till date, not much scientific research has been conducted in this Creek except the work of Olomukoro and Azubuike [14] and Olomukoro et al. [19] and it experiences pollution of heavy metals majorly from Chevron storage facilities, Warri Refinery and other anthropogenic activities.

The focus of the study was to assess the heavy metals concentrations in water and sediment of the creek by estimating mean values of metals in the stations as expressions of seasonal variation.

\section{MATERIALS AND METHODS}

\subsection{Study Area}

The study was conducted along the stretch of Ekpan Creek, Effurun, Delta State which is located within the oil rich Niger Delta, located within $5^{\circ} 3^{\prime} 5.11^{\prime \prime} \mathrm{N} 5^{\circ} 40^{\prime} 44.11$ 'E, altitude $13.5-$ $17.5 \mathrm{~m}$. The creek is about $12 \mathrm{~km}$ long and one of the major sinusoidal rivers which in conjunction form an astonishing tributary streams and creeks that drains the wetlands of the western Niger Delta. The river flows westerly into the creek at NNPC jetty and empties into Warri 
River at Bennet Island (Olomukoro et al. [19] and Emoyan et al. [2].

Major activities that characterized the study area was oil exploration activities from Chevron Nigeria Limited and petrochemical refining from the Warri Refinery and Petrochemical Company, a subsidiary of Nigerian National Petroleum Corporation (NNPC), Delta Development Property Agency (DDPA) where estate occupants directly dump waste into waters. Others are logging washing, bathing and swimming.

The study area is characterized by high relative humidity (80-92\%), annual average rainfall above $2800 \mathrm{~mm}$ and two distinct seasons (wet and dry). As a result of the fresh salt water mixture, a brackish environment is created at the banks of the river. The vegetation was made up of mangrove plants of different species, dominated by Rhizophora species.

\subsection{Sampling Locations}

Five sampling stations were carefully selected (Fig. 1) for their proximity to facilities, structures or human activities that could have potential impact on the water quality and or, aggravate pollution from December 2009 to May 2010 and, to cover for wet and dry seasons sampling. Station I was located downstream at Olare layout with water depth of $2.47 \pm 0.50 \mathrm{~m}$, flow velocity of $1.02 \pm 0.30 \mathrm{~m} / \mathrm{s}$ and the flow rate was minimal. The bank was flanked with red mangrove (Rhizophora racemosa), water hyacinths, and some shrubs. The water was murky and turbid from personal observation. The substratum is made of clay and mud. Human activities include fishing, aquaculture, bathing, laundry and farming. Station II was the DDPA estate. The water depth was $3.30 \pm 4.42 \mathrm{~m}$, with flow rate of $1.12 \pm 0.10 \mathrm{~m} / \mathrm{s}$, and faster than Station I. Marginal vegetation consists of Rhizophora recemosa (red mangrove), shrubs and few grasses. The water was murky and turbid. Human activities include fishing, laundry and the use of the water for construction. Station III substratum was a combination of silt and marsh. Marginal vegetation consists of mangrove, grasses and shrubs. It was located at the Ekpan new Layout, with water depth $(3.56 \pm 5.65 \mathrm{~m})$, and flow rate $(1.48 \pm 0.07 \mathrm{~m} / \mathrm{s})$ faster than that

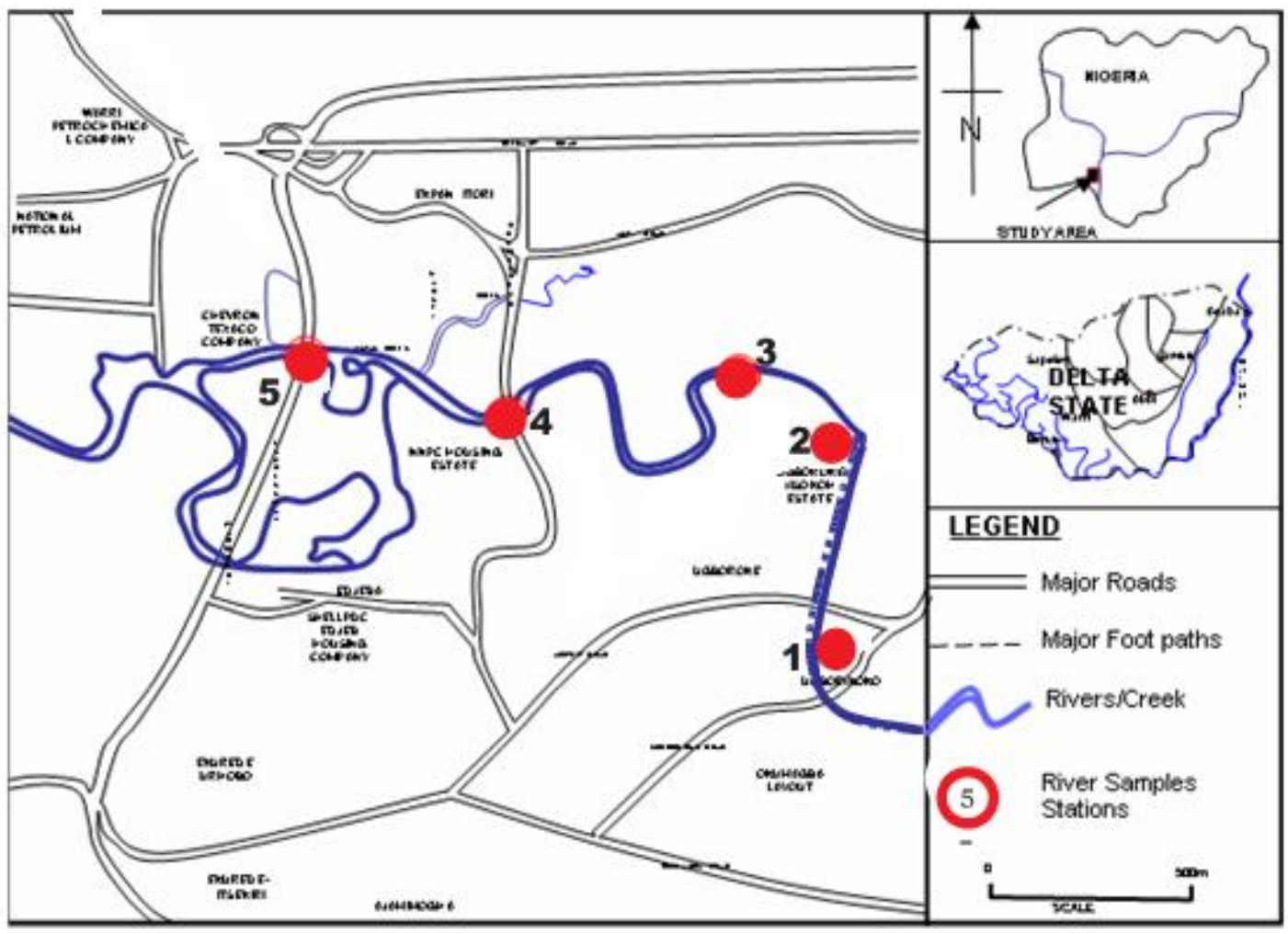

Fig. 1. Map of Warri showing sampled points 
of Station II. Human activities included logging, laundry and fishing. Station IV was under the Ekpan Bridge, close to NNPC housing complex. Water depth $(5.12 \pm 7.71 \mathrm{~m})$ and flow rate $(1.48$ $\pm 0.12 \mathrm{~m} / \mathrm{s}$ ). The substratum was also a combination of mud sand, silt, while the marginal vegetation consists of Rhizophora recemosa (red mangrove), shrubs, grasses and water hyacinths. The water surface was lined with oily films, turbid and murky. Human activities included aquaculture and sparse agricultural farms. Station $V$ was located $5 \mathrm{~km}$ away from Station IV, by Chevron-Texaco company bridge site. The water depth is $6.38 \pm 8.44 \mathrm{~m}$; the flow velocity at this station was very fast, about $1.50 \pm 0.18 \mathrm{~m} / \mathrm{s}$. The substratum was a mixture of sand and silt, with mangrove characterized forest vegetation, grasses and shrub. As expected, oily films dots the water surface with no physical human activity around expect for few fishermen going about their businesses; this could be as a result of the restriction enforced by the Uniform personnel assigned to the company.

\subsection{Samples Collection and Analysis}

Water and sediment collection were collected from five sampling stations from December 2009 to May 2010 at a time between 7.00 am and 9:30 am for six (6) months. This sampling time was chosen because human activities in the river were still very low and best to determine the physiochemical characteristics of fresh water bodies. Sampling containers were thoroughly washed with water, soaked in diluted nitric acid for four hours, thereafter rinsed with distilled water. Care was taken to avoid contamination of samples.

Water samples were collected monthly in appropriately labeled bottles. Those for chemical analysis into $1 \mathrm{~L}$ polythene bottles without acid, $\mathrm{BOD}$ in colored bottles; just below the water surface using the direct sampling method describe by APHA [20] and modified by USEPA [16]. While sediment samples were collected using a 6-inch Ekman grab into appropriately labeled black polythene bags for the study period.

Water samples were pretreated and digested using the wet oxidation method [21]. The Varian Techron Spectr AA - 10 Atomic Absorption Spectrometer (S/N.902 1318) with a printer attached was used for the quantitative determination of all heavy metals. The water samples already fixed in nitric acid [21] were filtered through Whatman filtered paper no 1 and aspirated directly into the AAS for metal such as $\mathrm{Cd}, \mathrm{Cu}, \mathrm{Pb}, \mathrm{Mn}, \mathrm{Ni}$ and $\mathrm{Zn}$. The blanks were prepared accordingly. For quality assurance purposes AAS was calibrated for each metal by dissolving 1 gram analar grade metal salt in 1 litre of distilled water. Standard and corresponding blanks were run with each set of experimental digest. The detection limits of zinc $(0.5 \mathrm{mg} / \mathrm{L})$, manganese $(0.5 \mathrm{mg} / \mathrm{L})$, copper $(0.05$ $\mathrm{mg} / \mathrm{L})$, nickel $(0.02 \mathrm{mg} / \mathrm{L})$, lead $(0.03 \mathrm{mg} / \mathrm{L})$, and cadmium $(0.01 \mathrm{mg} / \mathrm{L})$ were carefully observed. To ascertain quality control results of analysis were cross checked using standard reference materials for water and sediment; provided by FEPA [22].

Total organic matter content estimation was conducted using the percentage loss on Ignition (LOI) described by Allen [23]. TOM was observed to influence the partitioning of contaminants in sediments containing a large amount of organic matter in form of particulate, while sediments containing a small amount of organic matter may have a larger part of the contaminants present in the pore water

$\%$ loss on Ignition $=w t$ loss $(g)^{*} 100 / o v e n$ dry wt (g).

The system used was modified after Allen [23] and used as Standard International scale (International Soil Science Society). Particle Fractionation expresses the proportion of various sizes of particles present in a soil sample. In this system, particles sizes below $2.0 \mathrm{~mm}$ were graded using a successive sieving technique. A nest of sieves were mounted on a vibration machine and $10 \mathrm{~g}$ of the sediment sample introduced. The sieves separated the sediment into 3 size classes based on the particle diameter. The grades were read off from the scale, while the \% composition of each class was computed for each sample. Sediment samples were air dried, pre-treated and digested using procedure outlined by APHA [5] and modified by Olomukoro et al. [19]. $1 \mathrm{~g}$ of sediment was weighed into a beaker, $10 \mathrm{~mL}$ nitric and $5 \mathrm{~mL}$ perchloric acids were added. The mixture was heated for two hours, allowed to cool and kept overnight (about 20 hours). The supernatant was transferred to a clean beaker, while the sediment was washed with $10 \mathrm{~mL}$ of distilled water and added to the supernatant. The mixture was filtered through a Whatman no 42 filter paper into a $25 \mathrm{~mL}$ volumetric flask and made up to the mark. 
The Inductively Coupled Plasma-Mass Spectrometer (ICPMS) was used to ascertain the presence of possible heavy metals in few samples of water and sediment as suggested by Dojlido and Taboryska [24]. The ICP procedure describes a technique for simultaneous or sequential multielement determination of metals and trace elements in solution based on the measurement of atomic emission by an optical spectrometric technique.

\subsection{Statistical Analysis}

Analysis of variance (ANOVA), Regression, and correlation coefficients were carried out on data to show significant differences in the monthly metal concentrations in the water and sediment using the 2007 Excel and SPSS version 19 tool packages. Duncan Multiple Range test (DMR) was employed to ascertain the actual locations of the significant differences which occurred in the ANOVA.

Distribution coefficient (Kd) was used to determine the sorption capacity of the parameters into the sediment. Values less than 6 $\mathrm{mg} / \mathrm{L}$ were considered insignificant.

Distribution coefficient $(\mathrm{Kd})=\frac{\mathrm{M}_{\text {ads }}}{\mathrm{M}_{\text {sol }}}[25]$

Where $\mathrm{M}_{\mathrm{ads}}=$ metals adsorbed into the soil and $\mathrm{M}_{\text {sol }}=$ metal concentration in water.

\section{RESULTS AND DISCUSSION}

Mean concentrations of $\mathrm{Fe}, \mathrm{Cu}, \mathrm{Pb}, \mathrm{Cr}$, and $\mathrm{Mn}$ in the water of Ekpan Creek was stable throughout the period of study (Table 1). This temporally homogeneous concentrations of metals in the water may indicate some level of stability in the aquatic ecological equilibrium. There was a significant rise in the mean concentrations of $\mathrm{Zn}$ in January and February, 2010 above the rest of the months ( $P=0.05)$. The mean concentration of $\mathrm{Cd}$ in the water was significantly higher in March than other months $(P=0.05)$. The overall metals loads of the water body were within FEPA [22] regulatory limits for aquaculture, throughout the study period. This may imply that the anthropogenic activities are within safe limits; however this does not underscore the importance of constant biomonitoring of the aquatic environment.

Seasonally heterogeneous patterns of Iron (Fe), followed by zinc $(\mathrm{Zn})$ are apparent in the result (Fig. 2). Relatively high concentrations of $\mathrm{Zn}$ were particularly recorded towards the end of the dry season i.e. in January and February, 2010. Low concentrations were recorded in other heavy metals throughout the study period, except for a little rise in $\mathrm{Mn}$ concentration observed in January 2010.

As seen in Fig. 3, the sequence of metals levels in the water is $\mathrm{Fe}(69.5 \%)>\mathrm{Zn}(26 \%)>\mathrm{Mn}$ $(2.7 \%)>\mathrm{Cd}(0.8 \%)>\mathrm{Pb}(0.3 \%), \mathrm{Cu}(0.3 \%)$ and $\mathrm{Cr}(0.3 \%)$, in line with higher concentrations of Fe followed by $\mathrm{Zn}$ reported by Olomukoro and Azubuike [14] in Ekpan Creek. This sequence is at variance with that observed in Osse River (Fe $>\mathrm{Mn}>\mathrm{Zn}>\mathrm{Cu}>\mathrm{Pb}$ ) by Omoigberale and Ikponmwosa- Eweka [26]. It also disagrees with the sequence observed in Egbokodo

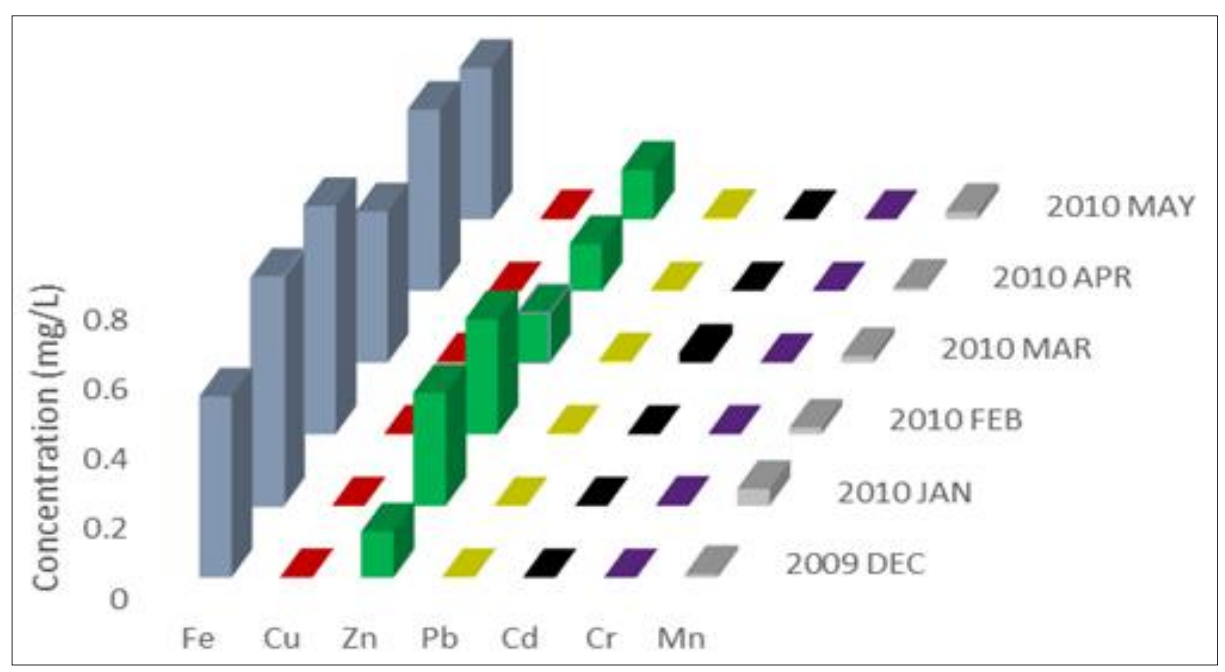

Fig. 2. Temporal variation of heavy metals in surface water 
River $(\mathrm{Fe}>\mathrm{Cd}>\mathrm{Cu}>\mathrm{Pb}>\mathrm{Mn}$ ) by Isibor and Oluowo [17]; and in River Benue ( $\mathrm{Fe}>\mathrm{Cr}>\mathrm{Pb}$ $>\mathrm{Mn}>\mathrm{Zn}>\mathrm{Cu}>\mathrm{Cd}$ ) by Eneji [27]. However, the conformity in the sequences among the rivers is domination of iron over other metals. This can be attributed to corresponding rates of anthropogenic sources of the iron in the rivers.

Outstandingly high concentrations were recorded in the iron of the bottom sediment throughout the study period (Table 2). This is an indication of high rate of deposition of iron in the bottom sediment. The observed concentration of iron in bottom sediment was quite higher than the FEPA recommended limit [22]. However no significant difference was recorded throughout the study period $(P=0.07)$.

Temporally heterogeneous metal loads were observed in the bottom sediment of the river (Table 2). The mean concentrations of $\mathrm{Cu}$ were significantly higher in December 2009 and January 2010 than in February to April 2010; which was significantly higher than the mean concentration in May, $2010(P=0.04)$; revealing a constant decline in copper concentrations from dry season into the rainy season. This can generally be attributed to the dilution of the concentration as a result of increased volume of water in the rainy season. The mean concentrations of Zinc in the sediment were significantly higher from January to March, 2010 than other parts of the study regime $(P=0.05)$. Significantly higher concentrations of all the metals; except iron, recorded in the sediment in the dry season than the wet season can be attributed to relatively higher metals loads in the overlying water column in the dry season due to reduced water volume. The reverse of the trend is expected in the overlying water in the wet season due to dilution process which culminates from increased water volume; particularly during plenty rains.

In comparison with Fig. 2, Fig. 3 shows relatively higher levels of metal loads in the bottom sediments. Fig. 6 further butresses the fact that an oustanding sorption of Iron occurred in the bottom sediment. This can be attributed to the repository nature of the bottom sediment and it confroms with the observation of Adams et al. [28] and Camusso et al. [29]. Result shows that Iron concentrations were outstandingly high in the bottom sediment. i.e. $\mathrm{Fe}$ had a relative percetage of $97.5 \%$ of the total metal loads, while other metals shared the remaining $2.5 \%$. There is correlation in the oustanding Iron levels in the water medium with that of the bottom sediment.

All the heavy metals have very high sorption capacities into the soil (Table 3) i.e. their sorption capacities are far higher than the significant level of $6 \mathrm{mg} / \mathrm{L}$ [28]. Iron (561.4 $\mathrm{mg} / \mathrm{L})$ sorption capacity into the bottom sediment from the water medium was outstandingly higher than other metals; while cadmium $(20 \mathrm{mg} / \mathrm{L})$ recorded the lowest sorption capacity. The sequence of the sorption was $\mathrm{Fe}>\mathrm{Cu}>\mathrm{Mn}>\mathrm{Cr}>\mathrm{Pb}>\mathrm{Zn}>\mathrm{Cd}$. Iron was the most adsorbed, while cadmium was the least adsorbed on the bottom sediment. The high sorption capacity observed in the aquatic environment necessitates constant careful biomonitoring, so as to put the concentrations of the metals in the sediment in constant check as the metals loads in bottom sediment can be reintroduced into the overlying water column; culminating in unprecedented eco-physiological hazards.

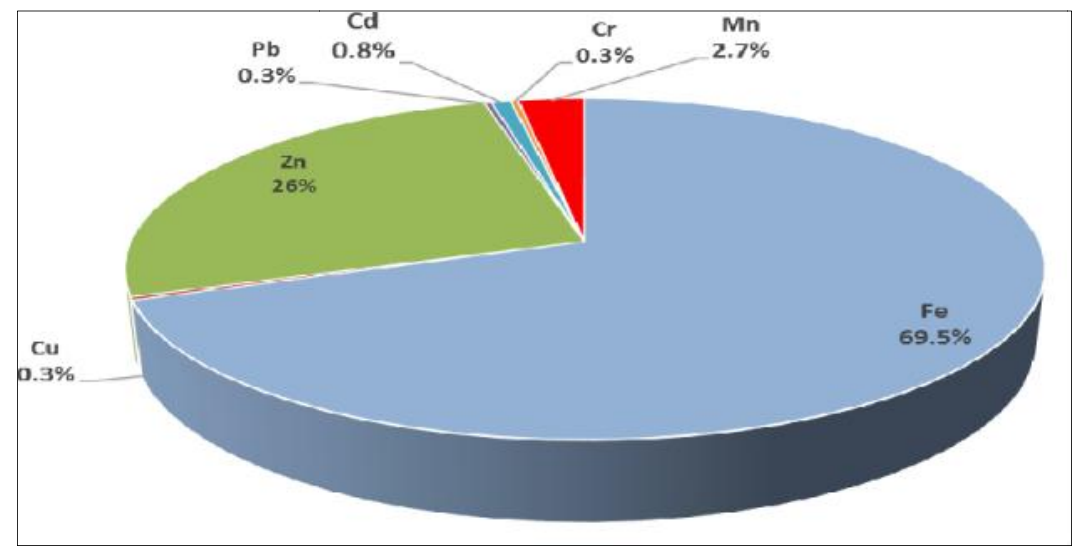

Fig. 3. Percentage distribution of heavy metals in surface water 
Table 1. Summary of temporal variation of heavy metals in surface water of Ekpan Creek (December, 2009 to May, 2010); $N=5$

\begin{tabular}{|c|c|c|c|c|c|c|c|c|}
\hline \multirow[t]{2}{*}{ Metals } & 2009 & \multicolumn{5}{|c|}{2010} & \multirow[t]{2}{*}{$P$ Value } & \multirow{2}{*}{$\begin{array}{l}\text { FEPA } \\
{[22]}\end{array}$} \\
\hline & Dec & Jan & Feb & Mar & Apr & May & & \\
\hline $\mathrm{Fe}(\mathrm{mg} / \mathrm{L})$ & $0.515 \pm 0.25(0.24-0.88)$ & $0.65 \pm 0.05(0.54-0.78)$ & $0.65 \pm 0.15(0.44-0.88)$ & $0.43 \pm 0.05(0.24-0.58)$ & $0.52 \pm 0.25(0.34-0.68)$ & $0.43 \pm 0.05(0.24-0.68)$ & $P=0.08$ & 20 \\
\hline $\mathrm{Cu}(\mathrm{mg} / \mathrm{L})$ & $0.001 \pm 0.001(0-0.002)$ & $0.001 \pm 0.01(0-0.002)$ & $0.002 \pm 0.01(0-0.003)$ & $0.004 \pm 0.01(0-0.005)$ & $0.002 \pm 0.01(0-0.004)$ & $0.003 \pm 0.01(0-0.005)$ & $P=0.09$ & $<1$ \\
\hline $\mathrm{Zn}(\mathrm{mg} / \mathrm{L})$ & $0.13 \pm 0.01(0-0.23)^{B}$ & $0.32 \pm 0001(0.1-0.43)^{A}$ & $0.328 \pm 0.1(0.1-0.43)^{A}$ & $0.14 \pm 0.1(0.1-0.33)^{\mathrm{B}}$ & $0.134 \pm 0.1(0.1-0.23)^{B}$ & $0.14 \pm 0.1(0.1-0.43)^{\mathrm{B}}$ & $P=0.05$ & 1 \\
\hline $\mathrm{Pb}(\mathrm{mg} / \mathrm{L})$ & $0.002 \pm 0.001(0-0.004)$ & $0.001 \pm 0.01(0-0.02)$ & $0.002 \pm 0.01(0-0.02)$ & $0.004 \pm 0.01(0.001-0.2)$ & $0.002 \pm 0.01(0.001-0.2)$ & $0.004 \pm 0.01(0.001-0.2)$ & $P=0.07$ & $<1$ \\
\hline $\mathrm{Cd}(\mathrm{mg} / \mathrm{L})$ & $0.001 \pm 0.01(0-0.2)^{B}$ & $0.001 \pm 0.01(0-0.2)^{B}$ & $0.001 \pm 0.01(0-0.02)^{B}$ & $0.029 \pm 0.01(0-0.3)^{\mathrm{A}}$ & $0.002 \pm 0.01(0-0.4)^{B}$ & $0.002 \pm 0.01(0-0.2)^{\mathrm{B}}$ & $P=0.05$ & $<1$ \\
\hline $\mathrm{Cr}(\mathrm{mg} / \mathrm{L})$ & $0.001 \pm 0.001(0-0.002)$ & $0.004 \pm 0.001(0-0.2)$ & $0.001 \pm 0.001(0-0.002)$ & $0.002 \pm 0.001(0-0.02)$ & $0.001 \pm 0.001(0-0.002)$ & $0.002 \pm 0.001(0-0.02)$ & $P=0.09$ & $<1$ \\
\hline $\mathrm{Mn}(\mathrm{mg} / \mathrm{L})$ & $0.01 \pm 0.001(0-0.002)$ & $0.049 \pm 0.001(0-0.02)$ & $0.019 \pm 0.001(0-0.02)$ & $0.019 \pm 0.001(0-0.02)$ & $0.01 \pm 0.002(0-0.04)$ & $0.021 \pm 0.001(0-0.01)$ & $P=0.08$ & 0.5 \\
\hline
\end{tabular}

NOTE: $P$ value less than or equal to 0.05 signifies significant difference, while values greater than 0.05 signifies no significant difference. Different letters indicate significant differences, while similar letters indicate no significant difference, $N=$ samples size, FEPA means Federal Environmental Protection Agency [22]

Table 2. Summary of temporal variation of heavy metals in bottom sediment of Ekpan Creek (December, 2009 to May, 2010); $\mathbf{N}=5$

\begin{tabular}{|c|c|c|c|c|c|c|c|c|}
\hline \multirow[t]{2}{*}{ Metals } & \multirow[t]{2}{*}{2009} & \multicolumn{6}{|c|}{2010} & \multirow{2}{*}{$\begin{array}{l}\text { FEPA } \\
\text { [22] }\end{array}$} \\
\hline & & Jan & Feb & Mar & Apr & May & $P$ Value & \\
\hline $\mathrm{Fe}(\mathrm{mg} / \mathrm{L})$ & $380.37 \pm 2.1(210.5-643.2)$ & $347.34 \pm 2.3$ & $314.9 \pm 1.9(208.5-553.8)$ & $323.4 \pm 2.3(198.5-543.2)$ & $281.29 \pm 2.8$ & $239.18 \pm 2$. & $P=0.07$ & 0.3 \\
\hline $\mathrm{Cu}(\mathrm{mg} / \mathrm{L})$ & $1.34 \pm 0.001(0.8-2.24)^{\mathrm{A}}$ & $1.19 \pm 0.001(0.2-3.44)^{\mathrm{A}}$ & $0.34 \pm 0.001(0.1-1.44)^{B}$ & $0.13 \pm 0.0001(0-4.22)^{B}$ & $0.12 \pm 0.0008(0-3.22)^{B}$ & $0.05 \pm 0.0001(0.001-1.22)^{\mathrm{C}}$ & ${ }^{*} P=0.04$ & 1 \\
\hline $\mathrm{Zn}(\mathrm{mg} / \mathrm{L})$ & $3.15 \pm 0.01(0.3-5.22)^{c}$ & $6.22 \pm 0.01(0.22-8.28)^{A}$ & $8.11 \pm 0.01(2.5-18.2)^{A}$ & $6.37 \pm 0.04(2.4-10.2)^{A}$ & $5.44 \pm 0.02(0.3-10.2)^{B}$ & $4.68 \pm 0.002(1.2-8.22)^{B}$ & ${ }^{*} P=0.05$ & 3 \\
\hline $\mathrm{Pb}(\mathrm{mg} / \mathrm{L})$ & $0.17 \pm 0.001(0-1.22)^{A}$ & $0.02 \pm 0.0001(0-1.28)^{B}$ & $0.06 \pm 0.003(0-12.22)^{B}$ & $0.12 \pm 0.004(0.01-4.22)^{\mathrm{A}}$ & $0.05 \pm 0.003(00.1-1.22)^{\mathrm{B}}$ & $0.023 \pm 0.001(0.01-1.22)^{\mathrm{B}}$ & ${ }^{*} P=0.05$ & 0.01 \\
\hline $\mathrm{Cd}(\mathrm{mg} / \mathrm{L})$ & $0.5 \pm 0.002(0.001-1.22)^{\mathrm{A}}$ & $0.06 \pm 0.007(0.01-1.28)^{B}$ & $0.05 \pm 0.002(0.01-1.32)^{B}$ & $0.04 \pm 0.001(0.003-1.22)^{B}$ & $0.03 \pm 0.007(0.003-1.22)^{B}$ & $0.02 \pm 0.0004(0.005-1.28)^{B}$ & ${ }^{*} P=0.05$ & 0.003 \\
\hline $\mathrm{Cr}(\mathrm{mg} / \mathrm{L})$ & $0.8 \pm 0.0001(0.003-1.72)^{A}$ & $0.007 \pm 0.0001(0.001-0.22)^{B}$ & $0.002 \pm 0.0001(0-0.22)^{B}$ & $0.002 \pm 0.0001(0-0.29)^{B^{\prime}}$ & $0.002 \pm 0.0001(0-0.42)^{\mathrm{B}^{\prime}}$ & $0.001 \pm 0.01(0-1.22)^{B}$ & ${ }^{*} P=0.05$ & 2 \\
\hline $\mathrm{Mn}(\mathrm{mg} / \mathrm{L})$ & $2.44 \pm 0.027(0.98-6.22)^{A^{\prime}}$ & $2.09 \pm 0.028(0.78-6.22)^{\mathrm{A}}$ & $1.63 \pm 0.0023(0.76-4.22)^{\mathrm{B}}$ & $1.45 \pm 0.042(0.34-5.22)^{B}$ & $1.2 \pm 0.0001(0-3.22)^{\mathrm{B}}$ & $0.87 \pm 0.0001(0.001-1.22)^{C}$ & ${ }^{*} P=0.04$ & 0.05 \\
\hline
\end{tabular}

samples size, FEPA means Federal Environmental Protection Agency [22] 


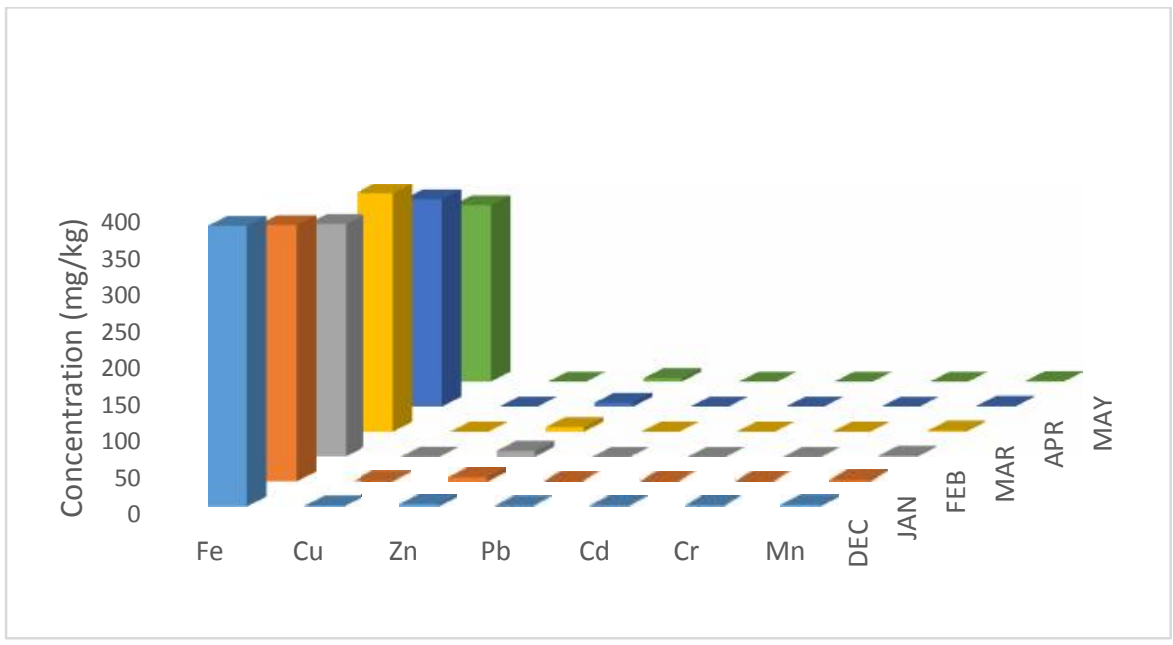

Fig. 4. Temporal variation of heavy metals in the bottom sediment

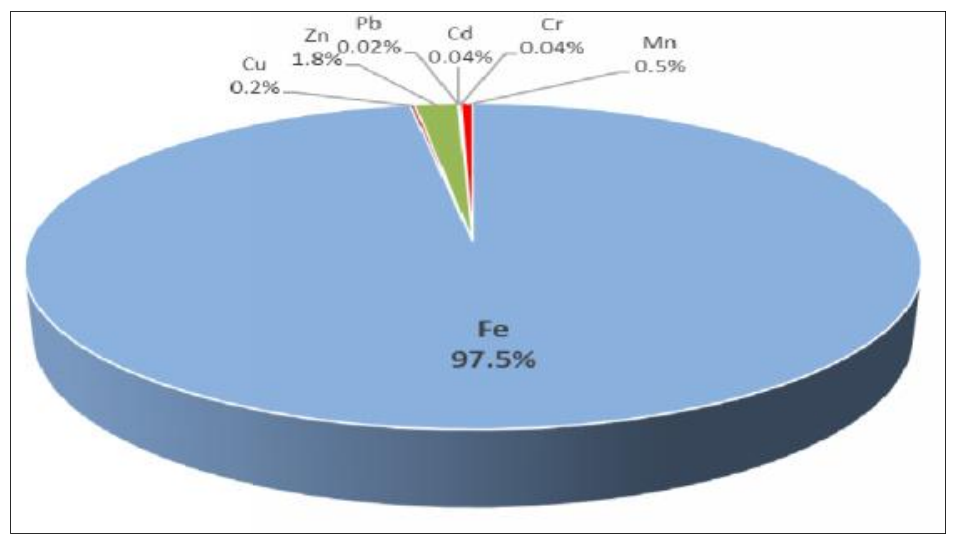

Fig. 5. Percentage distribution of heavy metals in bottom sediment

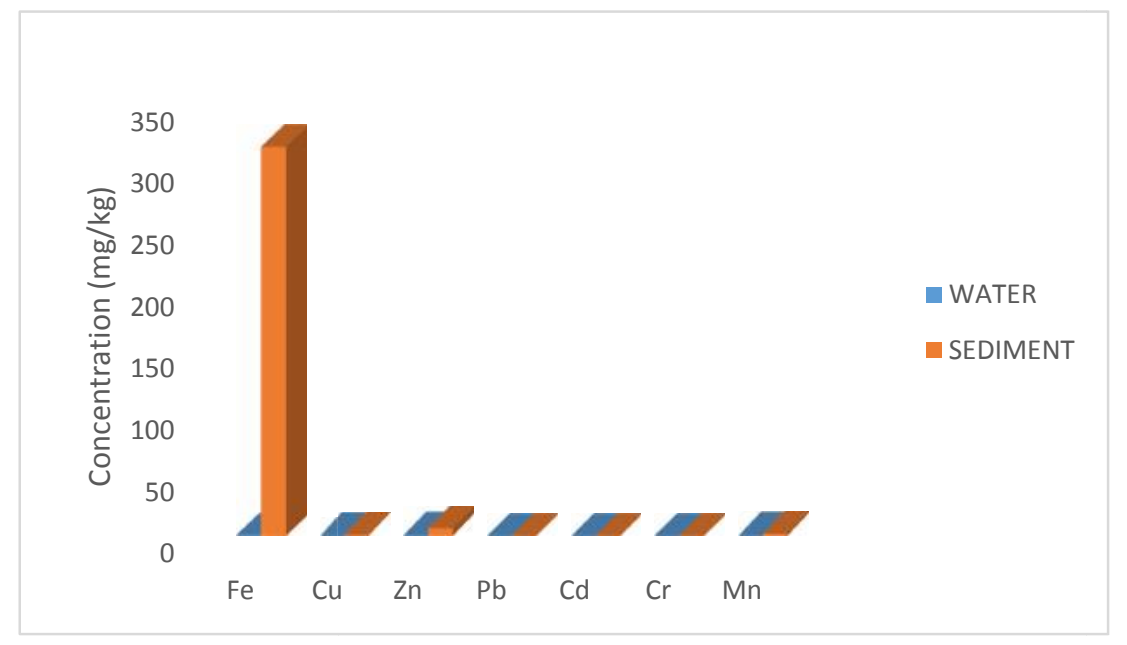

Fig. 6. Comparison between metal loads in surface water and bottom sediment 
Table 3. Distribution coefficients of parameters in sediment and water (mg/L)

\begin{tabular}{lllllll}
\hline Fe & Cu & Zn & Pb & Cd & Cr & Mn \\
\hline 561.4 & 262.5 & 28.46 & 32.61 & 20 & 71.58 & 75.76 \\
\hline
\end{tabular}

Apparent in the study, the concentrations of heavy metals in water was not in concomitant relationship with sediment concentrations, except for Iron, Zinc and Manganese. Higher concentrations of heavy metals were obtained in sediment than water which is expected; suggesting overtime pollution of the river and a property of sediment of being repository to heavy metal pollution. As seen in Figs. 3 and 5, the sequence of heavy metals concentrations in water and sediment did not follow a particular pattern, except Iron. This may have resulted from changing physiochemical conditions of the river, expecially temperature known to increase surface water dilution, metals solubility and sediment sorption capacity.

\section{CONCLUSION}

The study has provided vital information on the variability of metal loads in the river, for future reference on bio-monitoring studies. The river assimilative capacity and other dilution factors must have played an important role in attenuating surface water pollution in the Creek naturally during the wet season months with higher concentrations values obtained in sediment in dry season months. We suggest that the sources of $\mathrm{Fe}, \mathrm{Zn}$ and $\mathrm{Cu}$ be monitored through standard assessment studies in order to prevent possible ecological and public health risk.

\section{COMPETING INTERESTS}

Authors have declared that no competing interests exist.

\section{REFERENCES}

1. Sanders MJ. A field evaluation of freshwater river crab, Potamonautes warren, as a bioaccumulative indicator of metal pollution. Thesis, Rand Africans University, South Africa; 1997.

2. Emoyan OO, Ogban F, Akarah E. Evaluation of heavy metal loading of River ljana in Ekpan. Jour. Appli. Sci. Env. 2006;10(2):121-127.

3. Marian E. Metals and their compounds in the environment: Occurrence, analysis and biological relevance. UCH, Weinheim-New York-Basel-Cambridge. Ed; 1991.

4. Robinson KW, Lazaro $\mathrm{T}$, Pak C. Associations between water-quality trends in New Jersey streams and drainage-basin characteristics, 1975-86: U.S. Geological Survey Water-Resources Investigations Report. 1996;96-4119:148.

5. Adekoya JA, Williams OO, Ayejuya Williams OO. Distribution of heavy metals in sediment of Igbede, Ojo and ljora Rivers of Lagos. Nigeria. Environmentalist. 2006;26:277-280.

6. Rainbow PS, Dallinger R. Ecotoxicology of metals in invertebrates. Society of Environmental Toxicology and Chemistry Special Publication Series, Lewis Publishers, Boca Raton. 1993;461. ISBN 0-87371-734-I.

7. Ajao EA, Fagade SO. A study of the sediment and communities in Lagos Lagoon, Nigeria. Oil and Chemical Pollution. 1987;7:85-117.

8. Fufeyin PT. Heavy metal concentrations in the water, sediment and fishes of Ikpoba reservoir. Benin City. Nigeria. Ph.D (Thesis). 1994;167.

9. Erema RD, Hawkins SJ. Reproductive effects of heavy metals on the rough periwinkle saxatilis (Mollusca: Prosobranchia). Indian Journal of Marine Sci. 2002;218-224.

10. Ayenimo JG, Adeeyinwo CE, Amoo IA. Heavy metal pollutants in Warri River. Nigeria. Kragujevac J. Sci. 2005;27:43-50.

11. Ayenimo JG, Adeyinwo CA, Amoo IA, Odukudu FI. A preliminary investigation of heavy metals in periwinkles from Warri River, Nigeria. Journal of Applied Science. 2006;5(5):813-815.

12. Nduka JKC, Orisakwe OE. Heavy metal levels and physicochemical quality of portable water supply in Warri. Annali Di Chimical. 2007;97:867-874.

13. Puyate IT, Rim-Rukek A, Awatefe JK. Metal pollution assessment and particle size distribution of bottom sediment of Orogbodo River. Agbor. Delta State. Nigeria. Journal of Applied Research. 2007;3(12):2056-2061.

14. Olomukoro JO, Azubuike NC. Heavy metals and macroinvertebrate communities 
in bottom sediment of Ekpan Creek. Jordan Journal of Biological Sciences. 2009;2:1-8.

15. Stevens AO, Nnabuk OE. Studies on the use of Oyester snail and periwinkle shells as adsorbents for the removal of $\mathrm{Pb} 2+$ from aquatic solution. E. Journal of Chemistry. 2009;6(1):213-222.

16. United State Environmental Protection Agency (USEPA). List of contaminants and their maximum contamination limits. 2009;6.

17. Isibor PO, Oluowo EF. Evaluation of some heavy metals and total petroleum hydrocarbon in water and palaemonid shrimps (Macrobrachium vollenhovenii) of Egboko River, Warri, Delta State, Nigeria. Science Domain Journal of Applied Life Sciences International. 2016;6(4):1-12. DOI: $10.9734 / J A L S I / 2016 / 27148$

18. Mohamed EG, Hassan IF, Salem GS. Metal pollution assessment in the surface sediment of Lake Nasser, Eygpt. The Egyptian Journal of Aquatic Research. 2014;40(3):213-224.

19. Olomukoro JO, Osunde GA, Azubuike CN. Eichlornia crappies invasion and physiochemical characteristics of a creek flowing through an urban area in Southern Nigeria. African Scientist. 2009;10:1-14.

20. American Public Health Association (A.P.H.A). Standard methods for the elimination water and wastewater. $19^{\text {th }}$ American Public Health Association; 1997.

21. Martin GR, Smoot JL, White KD. A comparison of surface-grab and crosssectionally integrated stream-water -quality sampling methods. Water Environ. Res. 1992;64(7):866-876.

22. Federal Environmental Protection Agency (FEPA). Guidelines and Standards for Environmental Pollution Control in Nigeria. 2003;237-240.

23. Allen EB. The restoration of disturbed arid landscapes with special reference to Mycorrhizal fungi. Journal of Arid Environment. 1989;17:27-286.

24. Dojlildo JR, Best GAL. Chemistry of water and water pollution. Elli Horwood LTD Publishers; 1993.

25. Soares MR, Alleoni LRF. Distribution coefficient (KD) of heavy metals in Brazilian soils. 18th World Congress of Soil Sciences, Philadelphia, USA. 2006;134.

26. Omoigberale MO, Ikponmwosa- Eweka O. Evaluation of heavy metals of the Palaemonid Shrimps (Macrobrachium vollenhovenii) in Osse River, Nigeria. Bioscience Research Communications. 2010;22(5):247-254.

27. Eneji SI. Spatial and temporal variation in the heavy metals loading of River Benue in Makurdi metropolitan area, Ph. D. Thesis, Department of Chemistry University of Agriculture Makurdi, Nigeria. 2010;95.

28. Adams WJ, Kimerle RA, Barnet JW. Sediment quality and aquatic life assessment. Environmental Science and Technology. 1992;26:1865-1875.

29. Camusso M, Vigano L, Baistrini R. Bioaccumulation of trace metals in rainbow trout. Ecotoxicology and Environmental Safety. 1995;31:133-141.

(c) 2016 Freeman and Omoregie; This is an Open Access article distributed under the terms of the Creative Commons Attribution License (http://creativecommons.org/licenses/by/4.0), which permits unrestricted use, distribution, and reproduction in any medium, provided the original work is properly cited.

Peer-review history:

The peer review history for this paper can be accessed here: http://sciencedomain.org/review-history/16610 